\title{
Sistem Penunjang Keputusan Rekomendasi Kelulusan dan Pemeringkatan Santri Menggunakan Metode AHP-TOPSIS
}

\author{
$\underline{\text { Muhammad Auva Al-Marom }}{ }^{1}$, Setyawan Wibisono ${ }^{2}$ \\ Teknik Informatika, Fakultas Teknologi Informasi, Universitas Stikubank Semarang \\ Unisbank Kampus Mugas, Jl. Trilomba Juang No 1, Semarang, Indonesia \\ auvaalmaro@gmail.com ${ }^{1}$,setyawan@edu.unisbank.ac.id ${ }^{2}$
}

\begin{abstract}
Islamic boarding schools are one of the Islamic education institutions in Indonesia. In the graduation assessment process, it is carried out by the ustadz examiner and uses the manual method so that it is uncertain which will have an impact on the graduation of students. So we need a system that helps to determine graduation and ranking using a combination of AHP (Analytical Hierarchy Process) and TOPSIS (Technique for Order Preference by Similarity to Ideal Solution) methods. In AHP, there are four stages, namely: determining criteria, determining pairwise comparison tables, calculating priority weights and calculating the consistency of criteria. The criteria used refer to the target of passing the Islamic boarding school according to the pesantren's special curriculum, namely memorizing juz 30 and elective letters, reading the Taqrib book, becoming an imam, leading tahlil and Arabic conversations. AHP is used to help select candidates or just rank the priorities of several candidates. To determine the pairwise comparison table, first perform a comparison of the criteria in order to produce the relative weights between the criteria and alternatives. TOPSIS implementation includes finding alternative data, weighting alternatives, normalizing data, normalizing weighted, determining positive and negative ideal solutions, calculating ideal distances, resulting in ranking. This decision support system produces the highest preference value, namely 0.860862596 so that it can be used to recommend graduation and ranking of Hajroh Basyir Pati Islamic boarding school students based on predetermined criteria.
\end{abstract}

Keywords: ahp, graduation, ranking, decision support system, topsis

\begin{abstract}
Abstrak
Pondok pesantren merupakan salah satu lembaga pendidikan Islam yang ada di Indonesia. Dalam proses penilaian kelulusan dilakukan oleh ustadz penguji dan menggunakan cara manual sehingga bersifat tidak pasti yang akan berdampak pada kelulusan santri. Maka dibutuhkan suatu sistem yang membantu untuk menentukan kelulusan dan pemeringkatan dengan menggunakan kombinasi metode AHP (Analytical Hierarchy Process) dan TOPSIS (Technique for Order Preference by Similarity to Ideal Solution). Pada AHP terdapat empat tahapan yaitu: menentukan kriteria, menentukan tabel perbandingan berpasangan, menghitung bobot prioritas dan menghitung konsistensi kriteria. Kriteria yang digunakan, mengacu pada target kelulusan pondok pesantren sesuai dengan kurikulum khusus pesantren yaitu hafalan juz 30 dan surat pilihan, membaca kitab Taqrib, menjadi imam, memimpin tahlil dan percakapan bahasa Arab. AHP digunakan untuk membantu menyeleksi kandidat atau hanya mengurutkan prioritas dari beberapa kandidat. Untuk menentukan tabel perbandingan berpasangan terlebih dahulu melakukan perbandingan kriteria guna menghasilkan bobot relatif antar kriteria maupun alternatif. Implementasi TOPSIS meliputi mencari data alternatif, pembobotan alternatif, normalisasi data, normalisasi berbobot, menentukan solusi ideal positif dan negatif, menghitung jarak ideal, sehingga menghasilkan perangkingan. Sistem pendukung keputusan ini menghasilkan nilai preferensi tertinggi yaitu 0,860862596 sehingga dapat digunakan untuk merekomendasikan kelulusan dan pemeringkatan santri pondok pesantren Hajroh Basyir Pati berdasarkan kriteria yang telah ditetapkan.
\end{abstract}

Kata kunci : ahp, kelulusan, pemeringkatan, sistem pendukung keputusan, topsis

\section{Pendahuluan}

Negara Indonesia merupakan populasi muslim terbesar di dunia, sedangkan di Indonesia menjadi pusat dari pendidikan agama Islam yang ditandai dengan banyak ditemukannya pesantren dan sekolah madrasah yang dipimpin oleh kiai [1]. Santri merupakan seseorang yang belajar pendidikan agama Islam di pondok pesantren hingga lulus. Santri akan menempuh pendidikan formal dari pagi sampai siang hari, sedangkan untuk sore dan malam hari digunakan untuk mengaji kitab-kitab dan memahami ilmu-ilmu agama. Santri bisa dinyatakan lulus jika sudah melakukan ujian kompetensi dan mendapatkan penilaian yang diberikan oleh ustadz. Di pondok pesantren terdapat beberapa kompetensi yaitu hafalan juz 30 dan 
surat-surat pilihan, ilmu fiqih, dan ilmu nahwu shorof. Untuk mempertimbangkan penilaian santri, ustadz akan menguji hafalan juz 30 dan surat-surat pilihan, bacaan kitab Taqrib, kemampuan menjadi seorang imam hafalan tahlil, dan kelancaran bercakap menggunakan bahasa Arab. Untuk dapat menentukan peringkat tertinggi maka semua nilai hasil ujian diakumulasikan menjadi satu sehingga memperoleh hasil nilai paling tinggi. Tetapi ustadz dalam memberikan nilai masih secara subjektif, sehingga penilaian masih bersifat tidak pasti yang akan berdampak pada kelulusan santri.

Untuk mengatasi masalah tersebut maka dibuatlah sistem pendukung keputusan yang dikembangkan sebagai sistem pendukung untuk menyelesaikan permasalahan tidak terstruktur dan semiterstruktur serta meningkatkan pembuatan keputusan. Sistem bersifat interaktif yang bisa memberikan informasi, pemodelan, dan memanipulasi data [2]. Berdasarkan studi pustaka terdahulu yang ada beberapa kemiripan maka penelitian ini memakai metode Analytical Hierarchy Process (AHP) dan Technique for Order Preference by Similarity to Ideal Solution (TOPSIS). Metode AHP digunakan untuk menimbang atau mencari bobot kriteria kelulusan untuk setiap ujian, dan metode TOPSIS digunakan pada tahap perankingan.. Penggabungan kedua metode tersebut bertujuan untuk memberikan pertimbangan dan mempermudah pengurus dalam menentukan nilai kelulusan santri berdasarkan beberapa standar atau kriteria yang sudah ditentukan.

Metode AHP dipakai untuk membantu menyeleksi kandidat atau hanya mengurutkan prioritas dari beberapa kandidat, penggunaan pairwise comparison matrix guna menghasilkan bobot relatif antar kriteria maupun alternatif [3]. Untuk mendapatkan hasil yang tepat dan akurat dalam melakukan penyeleksian, maka dikombinasikan dengan metode TOPSIS sehingga didapatkan sejumlah alternatif yang mungkin sesuai dengan kedekatan dengan solusi ideal [4].

Sistem pendukung keputusan dinilai dapat menghasilkan data akurat dan tepat sasaran untuk mengevaluasi dan melakukan pemilihan, metode pengambilan keputusan yang multi criteria mampu menyeleksi keputusan terbaik dari sejumlah keputusan yang dihasilkan, untuk mempercepat proses dan mendapatkan hasil keputusan terbaik. Pengambilan keputusan multi criteria dapat menggunakan metode TOPSIS, karena bisa memilih alternatif terbaik dari sejumlah alternatif. Sedangkan untuk mengambil suatu keputusan, metode AHP memliki indikator keberhasilan yang tinggi sehingga dapat digunakan untuk membandingkan setiap kriteria karena memiliki kecocokan untuk melakukan perhitungan multi criteria yang dapat memperoleh nilai prioritas dari masing-masing variable [5][6].

Metode TOPSIS digunakan dikarenakan menjadi konsep pilihan yang utama, kemudian mempunyai jarak terpendek dari solusi ideal positif, dan juga mempunyai jarak terpanjang solusi ideal negatif. Dalam kriteria manfaat semakin besar nilainya maka lebih layak untuk dipilih Sedangkan untuk kritera biaya kebalikannya, maka dalam TOPSIS mempertimbangkan keduanya sehinga dapat memberikan solusi terhadap permasalahan yang ada [4][7]. Metode TOPSIS bisa digunakan secara hybrid dengan metode Analytical Hierarchy Process (AHP) untuk perhitungan bobot, karena AHP membandingkan tingkat kepentingan tiap kriteria yang nantinya digunakan untuk menghasilkan bobot kriteria yang konsisten, selain itu AHP mempunyai kemampuan untuk memecahkan masalah dengan banyak kriteria. Metode ini sangat fleksibel, dengan artian mampu mencakup semua masalah dengan tujuan dan kriteria yang beragam, sehingga menghasilkan urutan alternatif dari hasil yang tertinggi ke hasil yang terendah, dengan pemberian nilai pada semua kriteria yang telah ditetapkan [8]. Metode AHP mengasumsikan bahwa pembuat keputusan dapat memberikan estimasi poin yang tepat dari preferensi mereka untuk alternatif. Metode AHP digunakan untuk perhitungan aritmatika sehingga memperoleh bobot additive, dan keseluruhan hasil bobotnya dijumlahkan. Didalam proses hierarki analitik, ada tiga prinsip utama dalam metode AHP, yaitu prinsip pengaturan hierarki, prinsip penentuan prioritas, dan prinsip konsistensi logis [9].

Oleh karena itu, dengan menggabungkan kedua metode ini diharapkan akan membantu dalam menyelesaikan persoalan kelulusan dan pemeringkatan santri yang ada di Pondok Pesantren Hajroh Basyir Pati.

\section{Metodologi}

Dalam penyusunan penelitian diperlukan sebuah kerangka kerja (frame work) agar mempermudah untuk menguraikan tahapan-tahapan. Frame work yang digunakan dalam penelitian ini yaitu: 


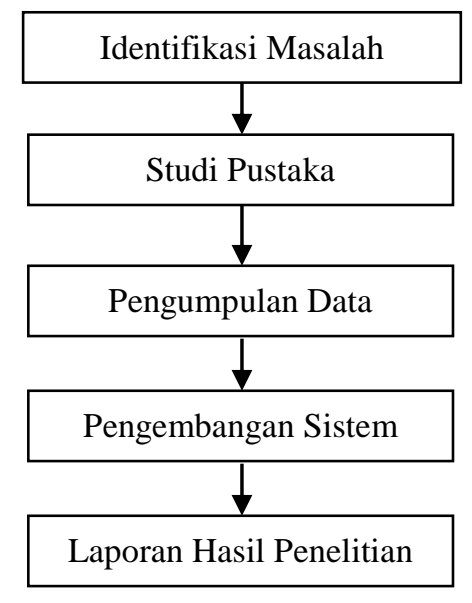

Gambar 1. Framework Penelitian

Berdasarkan frame work yang telah dibuat, maka dapat dijelaskan bahwa indentifikasi masalah adalah tahap yang digunakan untuk memecahkan masalah yang terjadi di pondok pesantren Hajroh Basyir Pati dalam menetukan kelulusan dan pemeringkatan santri. Pada tahap studi pustaka dilakukan pencarian tentang landasan teori melalui sumber yang terkait seperti buku referensi, artikel, jurnal, Unified Modeling Language (UML), PHP dan MySQL dan literatur-literatur tentang masalah sistem pendukung keputusan metode AHP dan TOPSIS. Pengumpulan data adalah faktor utama yang dibutuhkan untuk mencari atau mengumpulkan data dalam penelitian, pengumpulan data diperoleh dari hasil wawancara dan analisa dokumen. Untuk metode pengembangan sistem memakai metode waterfall dikarenakan untuk pengaplikasiannya yang urut dan sistematis. Laporan hasil penelitian digunakan sebagai gambaran sistem yang sedang dibangun untuk menyelesaikan masalah di pondok pesantren Hajroh Basyir Pati.

Proses implementasi pada metode AHP terdapat empat tahapan yaitu menentukan kriteria, menentukan tabel perbandingan berpasangan, menghitung bobot proiritas dan menghitung konsistensi kriteria. Penentuan kriteria berguna pada proses menentukan kriteria apa saja yang akan digunakan. Kriteria yang digunakan mengacu pada target kelulusan pondok pesantren sesuai dengan kurikulum khusus pesantren itu sendiri yaitu dari nilai hafalan juz 30 dan surat pilihan, nilai membaca kitab Taqrib, nilai menjadi imam, nilai memimpin tahlil dan nilai percakapan bahasa Arab. Kemudian untuk menentukan tabel perbandingan berpasangan terlebih dahulu melakukan perbandingan kriteria yang digunakan ke dalam bentuk matriks. Nilai matriks dari perbandingan kriteria diisi dari angka 1 (satu) sampai dengan angka 9 (sembilan), tetapi untuk perbandingan nilai matriks yang sama harus diisi dengan angka 1 (satu), kemudian dijumlahkan perkolom. Untuk melihat bobot proiritas harus membandingkan kriteria dengan membagi isi matrik hasil perbandingan dengan total kolom yang sesuai setelah itu melakukan penjumlahan baris, hasil dari penjumlahan dibagi dengan jumlah kriteria yang nantinya akan menghasilkan bobot prioritas. Untuk konsistensi kriteria dilakukan dengan cara mengalikan semua isi kolom perbandingan kriteria A dengan bobot prioritas kriteria A, isi kolom perbandingan kriteria B dengan bobot prioritas kriteria B dan seterusnya. Kemudian dijumlahkan setiap barisnya dan dibagi dengan penjumlahan baris bobot prioritas.

Sistem pemeringkatan ini memakai penggabungan dua metode yaitu AHP dan TOPSIS. Metode TOPSIS nantinya untuk mencari siapa yang mendapatkan nilai terbaik menggunakan model pemeringkatan. Implementasi dari metode TOPSIS ada beberapa tahap yaitu mencari data alternatif, pembobotan alternatif, normalisasi data, normalisasi berbobot, menentukan solusi ideal positif dan negatif, meghitung jarak ideal, sehingga menghasilkan perangkingan.

\section{Hasil dan Pembahasan}

\subsection{Analytic Hierarchy Process (AHP)}

Pada dasarnya tahap-tahap dalam metode AHP meliputi:

1. Menentukan alternatif dan kriteria.

2. Memasukkan kriteria ke matrik berpasangan. 
3. Menambahkan semua nilai dari masing-masing kolom pada matrik.

4. Membagi nilai dari kolom dengan keseluruhan kolom yang berguna untuk mendapatkan normalisasi matrik.

5. Menambahkan masing-masing nilai permatrik dan membagi dengan semua elemen untuk memperoleh nilai rata-rata [10].

\subsection{Technique for Order Preference by Similarity to Ideal Solution (TOPSIS)}

Langkah-langkah dalam pembuatan metode TOPSIS:

1. Pembuatan matrik perbandingan berpasangan yang ternormalisasi.

$$
r_{i j} \frac{x_{i j}}{\sqrt{\sum_{i=1}^{m} x_{i j}^{2}}}
$$

Dengan $i=1,2, . . m$; dan $j=1,2, . . n$;

Di mana $r_{\mathrm{i} j}=$ Elemen matriks ternormalisasi [i][j], $X_{\mathrm{i} j}=$ Elemen matriks keputusan $\mathrm{X}$

2. Pembuatan matrik keputusan yang ternormalisasi berbobot.

$$
y_{i j}=w_{i} x_{i j}
$$

Dengan $i=1,2, . . m$; dan $j=1,2, . . n$;

Di mana $Y_{i j}=$ Elemen matriks ternormalisasi [i][j], $w_{i}=$ Bobot [i] dari proses AHP

3. Penentuan matrik solusi ideal positif dan matrik solusi ideal negatif.

$$
\begin{aligned}
& A^{+}=\left(y_{1}^{+}, y_{2}^{+}, \ldots, y_{n}^{+}\right) ; \\
& A^{-}=\left(y_{1}^{-}, y_{2}^{-}, \ldots, y_{n}^{-}\right) ;
\end{aligned}
$$

Di mana $y_{j}^{+}=\max _{i} Y_{i j}$; jika $\mathrm{j}$ adalah atribut keuntungan, $\min _{\mathrm{i}} \mathscr{Y}_{\mathrm{ij}}$; jika $\mathrm{j}$ adalah atribut biaya dan $y_{j}^{+}=\min _{i} y_{i j} ;$ jika $\mathrm{j}$ adalah atribut keuntungan, $\max _{i} y_{i j} ;$ jika $\mathrm{j}$ adalah atribut biaya

4. Menentukan jarak antara nilai setiap alternatif dengan matriks solusi ideal positf dan negatif.

$$
\begin{gathered}
D_{i}^{+}=\sqrt{\sum_{j}^{n}=1\left(y_{i j}-y_{i}^{+}\right)^{2}} \\
D_{i}^{-}=\sqrt{\sum_{j}^{n}=1\left(y_{i j}-y_{i}^{-}\right)^{2}}
\end{gathered}
$$

Di mana $D_{i}^{+}=$Jarak alternatif ke-i dengan solusi ideal positif, $y_{i j}=$ Elemen matriks ternormalisasi terbobot $[\mathrm{i}][\mathrm{j}],{y_{\mathrm{i}}^{+}}^{+}=$Elemen solusi ideal positif [i], $D_{\mathrm{i}}^{-}=$Jarak alternatif ke-i dengan solusi ideal negatif, dan $y_{i}^{-}=$Elemen solusi ideal negatif [i]

5. Menentukan nilai preferensi untuk setiap alternatif.

$$
V_{i}=\frac{D_{i}^{-}}{D_{i}^{-}+D_{i}^{+}}
$$

Di mana $V_{i}=$ Kedekatan tiap alternatif terhadap solusi ideal, $D_{i}^{-}=$jarak alternatif ke-i dengan solusi ideal negatif, $D_{i}^{+}=$jarak alternatif ke-i dengan solusi ideal positif.

Nilai Vi yang lebih tinggi menunjukan bahwa alternatif ke-i yang akan dipilih terlebih dahulu [4].

Penerapan metode AHP-TOPSIS dalam penentuan hasil kelulusan ujian dapat mempercepat dan akurat untuk memberikan informasi mengenai kelulusan dan pemeringkatan. 
Tabel 1. Daftar Alternatif

\begin{aligned} & \hline Kode Nama Alternatif \\ & \hline S1 Abi Manyu Deswa Sulistyo \\ & S2 Arvel Marcereno \\ & S3 Muhammad Fajar Maulana Al-Mansyur \\ & S4 Muhammad Hafidzurrohman \\ & S5 Muhammad Zakariya Al Musthofa \\ & S6 Laura Nur Shintia Maharani \\ & S7 Lisa Pravita Samsulhadi \\ & S8 Nabila Nur Aini \\ & S9 Nasywa Nabiilah Azzah \\ & S10 Nehayatus Sholekha Januarisky \\ & \hline\end{aligned}

Pada tabel 1 merupakan data alternatif yang dimana kode S1 menjelaskan nama alternatif dari Abi Manyu Deswa Sulistyo, kode dari S2 menjelaskan nama alternatif dari Arvel Marcereno, kode dari S3 menjelaskan nama alternatif dari Muhammad Fajar Maulana Al-Mansyur, kode dari S4 menjelaskan nama alternatif dari Muhammad Hafidzurrohman, kode dari S5 menjelaskan nama alternatif dari Muhammad Zakariya Al Musthofa, kode dari S6 menjelaskan nama alternatif dari Laura Nur Shintia Maharani, kode dari S7 menjelaskan nama alternatif dari Lisa Pravita Samsulhadi, kode dari S8 menjelaskan nama alternatif dari Nabila Nur Aini, kode dari S9 menjelaskan nama alternatif dari Nasywa Nabiilah Azzah, kode dari S10 menjelaskan nama alternatif dari Nehayatus Sholekha Januarisky.

Tabel 2. Daftar Kriteria

\begin{tabular}{cl}
\hline Kode & Nama Kriteria \\
\hline K1 & Hafal juz 30 dan surat pilihan \\
K2 & Membaca kitab Taqrib \\
K3 & Menjadi imam solat \\
K4 & Memimpin tahlil \\
K5 & Percakapan bahasa Arab \\
\hline
\end{tabular}

Pada tabel 2 merupakan daftar kriteria yang dimana kode dari K1 menjelaskan kriteria kelulusan dari hafal juz 30 dan surat pilihan, kode dari K2 menjelaskan kriteria kelulusan dari membaca kitab Taqrib, kode dari K3 menjelaskan kriteria kelulusan dari menjadi imam solat, kode dari K4 menjelaskan kriteria kelulusan dari memimpin tahlil, kode dari K5 menjelaskan kriteria kelulusan dari percakapan bahasa Arab.

Dalam menentukan bobot kriteria menggunakan matode Analytic Hierarchy Process (AHP). Berdasarkan langkah-langkah metode penelitian dan lima kriteria permasalahan tersebut, maka pengimplementasiannya dilakukan pada kasus kelulusan santri.

Wawancara dengan pihak pondok pesantren Hajroh Basyir Pati sudah dilakukan sehimgga mendapatkan kriteria-kriteria prioritas, seperti:

1. Hafalan juz 30 dan surat pilihan rata-rata antara sama penting dan sedikit lebih penting dari bacaan kitab Taqrib.

2. Hafalan juz 30 dan surat pilihan sedikit lebih penting dari menjadi imam.

3. Hafalan juz 30 dan surat pilihan sedikit lebih penting dari hafalan tahlil.

4. Hafalan juz 30 dan surat pilihan sedikit lebih penting dari percakapan bahasa Arab.

5. Bacaan kitab Taqrib rata-rata antara sama penting dan sedikit lebih penting dari menjadi imam.

6. Bacaan kitab Taqrib sedikit lebih penting dari hafalan tahlil.

7. Bacaan kitab Taqrib sedikit lebih penting dari percakapan bahasa Arab.

8. Menjadi imam rata-rata antara sama penting dan sedikit lebih penting dari hafalan tahlil.

9. Menjadi imam sedikit lebih penting dari percakapan bahasa Arab.

10. Hafalan tahlil rata-rata antara sama penting dan sedikit lebih penting dari percakapan bahasa Arab. 
Penentuan nilai kriteria perbandingan berpasangan pembuat keputusan yang digunakan sebagai seperti tabel 3 berikut.

Tabel 3. Nilai Kriteria Perbandingan

\begin{tabular}{ll}
\hline Nilai & Keterangan \\
\hline 1 & Sama penting \\
2 & Mendekati sedikit lebih penting dari \\
3 & Sedikit lebih penting dari \\
4 & Mendeketi lebih penting dari \\
5 & Lebih penting dari \\
6 & Mendekati sangat penting dari \\
7 & Sangat penting dari \\
8 & Mendekati mutlak dari \\
9 & Mutlak sangat penting dari \\
\hline
\end{tabular}

Tabel 3 merupakan perbandingan pasangan (pairwise compraison). Perbandingan berpasangan ini untuk membuat keputusan untuk membandingkan dari dua alternatif berdasarkan kriteria-kriteria yang sudah ditentukan dan mengindikasikan sebuah preferensi.

1. Menentukan tabel perbandingan berpasangan.

Tabel 4. Perbandingan Berpasangan Kriteria

\begin{tabular}{|c|ccccc}
\hline & K1 & K2 & $\mathbf{K 3}$ & $\mathbf{K 4}$ & $\mathbf{K 5}$ \\
\hline $\mathbf{K 1}$ & 1 & 2 & 3 & 3 & 3 \\
$\mathbf{K 2}$ & 0,5 & 1 & 2 & 3 & 3 \\
$\mathbf{K 3}$ & 0,3 & 0,5 & 1 & 2 & 3 \\
$\mathbf{K 4}$ & 0,3 & 0,3 & 0,5 & 1 & 2 \\
$\mathbf{K 5}$ & 0,3 & 0,3 & 0,3 & 0,5 & 1 \\
\hline Jumlah & $\mathbf{2 , 5}$ & $\mathbf{4 , 1 6 7}$ & $\mathbf{6 , 8 3}$ & $\mathbf{9 , 5}$ & $\mathbf{1 2}$ \\
\hline
\end{tabular}

Pada tabel 4 merupakan proses penentuan tabel perbandingan berpasangan menggunakan penilaian perbandingan kriteria ujian yang sudah ditentukan, berdasarkan perbandingan kriteria yang tabel Saaty.

Angka 1 yang ada di kolom K1 baris K1 menunjukkan tingkat kepentingan yang sama antara hafalan juz 30 dan surat-surat pilihan dengan hafalan juz 30 dan surat-surat pilihan, sedangkan angka 2 di kolom K2 baris K1 menunjukkan bahwa hafalan juz 30 dan surat-surat pilihan mendeketi sedikit lebih penting dibandingkan membaca kitab Taqrib. Angka 0,5 yang ada di kolom K1 baris K2 adalah hasil dari perhitungan angka 1 yang ada di kolom K1 dan baris K1 dibagi dengan angka 2 di kolom $\mathrm{K} 2$ baris K1. Begitupun dengan angka yang lainnya yang didapatkan dengan perhitungan yang sama.

2. Menghitung bobot proiritas

Tabel 5. Pembagian Nilai Matriks Perbandingan

\begin{tabular}{|c|ccccc}
\hline & K1 & K2 & K3 & K4 & K5 \\
\hline K1 & $1 / 2,5$ & $2 / 4,167$ & $3 / 6,83$ & $3 / 9,5$ & $3 / 12$ \\
K2 & $0,5 / 2,5$ & $1 / 4,167$ & $2 / 6,83$ & 39,5 & $3 / 12$ \\
K3 & $0,3 / 2,5$ & $0,5 / 4,167$ & $1 / 6,83$ & 29,5 & $3 / 12$ \\
K4 & $0,3 / 2,5$ & $0,3 / 4,167$ & $0,5 / 6,83$ & 19,5 & $2 / 12$ \\
K5 & $0,3 / 2,5$ & $0,3 / 4,167$ & $0,3 / 6,83$ & $0,59,5$ & $1 / 12$ \\
\hline
\end{tabular}


Pada tabel 5 merupakan proses perhitungan bobot prioritas yang membagikan isi matrik perbandingan dengan jumlah kolom yang sesuai selanjutnya melakukan penjumlahan perbaris kemudian dibagi dengan jumlah kriteria.

Di kolom K1 jumlah dari kolom K1 adalah 2,5, angka 1 di kolom K1 baris K1 dibagi dengan 2,5 yang menghasilkan angka 0,4, angka 0,3 di kolom K1 baris K2 dibagi dengan 2,5 yang menghasilkan angka 0,2. Begitupun dengan angka yang lainnya yang didapatkan dengan perhitungan yang sama.

Tabel 6. Bobot Prioritas

\begin{tabular}{|c|cccccc}
\hline & K1 & K2 & K3 & K4 & K5 & Bobot Prioritas \\
\hline K1 & 0,4 & 0,48 & 0,439024 & 0,315789 & 0,25 & 0,376962773 \\
K2 & 0,2 & 0,24 & 0,292683 & 0,315789 & 0,25 & 0,25969448 \\
K3 & 0,13 & 0,12 & 0,146341 & 0,210526 & 0,25 & 0,172040223 \\
K4 & 0,13 & 0,08 & 0,073171 & 0,105263 & 0,167 & 0,111686778 \\
K5 & 0,13 & 0,08 & 0,04878 & 0,052632 & 0,083 & 0,079615747 \\
\hline
\end{tabular}

Pada tabel 6 merupakan hasil pembagian dari semua kolom dan baris dengan jumlah kolom masingmasing kolom kriteria.

Setelah mendapatkan nilai bobot prioritas, langkah selanjutnya yang dilakukan adalah perangkingan menggunakan metode Technique for Order Preference by Similarity to Ideal Solution (TOPSIS) untuk mendapatkan peringkat tertinggi dengan tahapan seperti berikut:

1. Sampel nilai santri digunakan sebagai alternatif data untuk menentukan kelulusan dan pemeringkatan santri seperti tabel 8 berikut:

Tabel 7. Nilai Alternatif

\begin{tabular}{|c|ccccc}
\hline & K1 & K2 & K3 & K4 & K5 \\
\hline S1 & 8 & 8 & 10 & 8 & 6 \\
S2 & 6 & 8 & 10 & 8 & 6 \\
S3 & 8 & 8 & 10 & 8 & 8 \\
S4 & 8 & 6 & 10 & 10 & 6 \\
S5 & 6 & 8 & 8 & 8 & 8 \\
S6 & 10 & 8 & 10 & 10 & 8 \\
S7 & 8 & 6 & 8 & 8 & 10 \\
S8 & 8 & 6 & 8 & 8 & 8 \\
S9 & 6 & 10 & 8 & 6 & 10 \\
S10 & 10 & 8 & 10 & 8 & 8 \\
\hline
\end{tabular}

Pada tabel 7 merupakan sample nilai santri yang dipakai untuk perangkingan menggunakan metode Technique for Order Preference by Similarity to Ideal Solution (TOPSIS).

2. Pembuatan matrik perbandingan berpasangan yang ternormalisasi.

Rumus penghitungan normalisasi untuk kriteria adalah:

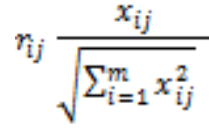

Pada tabel 8 merupakan hasil normalisasi perbandingan berpasangan. 
Tabel 8. Hasil Normalisasi Data

\begin{tabular}{|c|ccccc}
\hline & K1 & K2 & K3 & K4 & K5 \\
\hline S1 & 564,125 & 528,125 & 756,1 & 620,125 & 592,1667 \\
S2 & 564,0938 & 528,125 & 756,1 & 620,125 & 592,1667 \\
S3 & 564,125 & 528,125 & 756,1 & 620,125 & 592,2222 \\
S4 & 564,125 & 528,0938 & 756,1 & 620,1563 & 592,1667 \\
S5 & 564,0938 & 528,125 & 756,08 & 620,125 & 592,2222 \\
S6 & 564,1563 & 528,125 & 756,1 & 620,1563 & 592,2222 \\
S7 & 564,125 & 528,0938 & 756,08 & 620,125 & 592,2778 \\
S8 & 564,125 & 528,0938 & 756,08 & 620,125 & 592,0938 \\
S9 & 564,0938 & 528,1563 & 756,08 & 620,0938 & 592,2778 \\
S10 & 564,1563 & 528,125 & 756,1 & 620,125 & 592,2222 \\
\hline
\end{tabular}

Cara untuk mendapatkan nilai normalisasi dari alternatif dengan setiap kriterianya seperti:

$\mathrm{R}_{11}=8 / 8^{2}+6^{2}+8^{2}+8^{2}+6^{2}+10^{2}+8^{2}+8^{2}+6^{2}+10^{2}=564,125$

$\mathrm{R}_{12}=6 / 8^{2}+6^{2}+8^{2}+8^{2}+6^{2}+10^{2}+8^{2}+8^{2}+6^{2}+10^{2}=564,0938$

$\mathrm{R}_{13}=8 / 8^{2}+6^{2}+8^{2}+8^{2}+6^{2}+10^{2}+8^{2}+8^{2}+6^{2}+10^{2}=564,125$

Begitupun dengan alternatif lain menggunakan semua kriteria yang ditetapkan.

3. Membuat matriks keputusan yang ternormalisasi terbobot.

Rumus untuk mendapatkan nilai bobot ternormalisasi adalah:

$y_{i j}=w_{i} x_{\mathrm{i} j}$

Dimana didapatkan Wi (Bobot Kriteria) akan dikalikan dengan nilai normalisasi. Pada tabel 9 menunjukkan hasil normalisasi terbobot.

Tabel 9. Hasil Normalisasi Data Terbobot

\begin{tabular}{|c|ccccc}
\hline & K1 & K2 & K3 & K4 & K5 \\
\hline S1 & 212,6541242 & 137,1511 & 130,0796 & 69,25976 & 47,14579 \\
S2 & 212,6423441 & 137,1511 & 130,0796 & 69,25976 & 47,14579 \\
S3 & 212,6541242 & 137,1511 & 130,0796 & 69,25976 & 47,15021 \\
S4 & 212,6541242 & 137,143 & 130,0796 & 69,26325 & 47,14579 \\
S5 & 212,6423441 & 137,1511 & 130,0762 & 69,25976 & 47,15021 \\
S6 & 212,6659043 & 137,1511 & 130,0796 & 69,26325 & 47,15021 \\
S7 & 212,6541242 & 137,143 & 130,0762 & 69,25976 & 47,15464 \\
S8 & 212,6541242 & 137,143 & 130,0762 & 69,25976 & 47,13999 \\
S9 & 212,6423441 & 137,1593 & 130,0762 & 69,25627 & 47,15464 \\
S10 & 212,6659043 & 137,1511 & 130,0796 & 69,25976 & 47,15021 \\
\hline
\end{tabular}

Cara untuk mendapatkan nilai normalisasi dari alternatif dengan setiap kriterianya seperti:

$\mathrm{Y}_{11}=0,376962773 * 564,125=212,6541242$

$\mathrm{Y}_{12}=0,25969448 * 528,125=137,1511$

$\mathrm{Y}_{13}=0,172040223 * 756,1=130,0796$

Begitupun dengan alternatif lain dengan semua kriteria yang ditetapkan.

4. Menentukan matriks solusi ideal positif $\left(D^{+}\right)$dan matriks solusi ideal negative $\left(D^{-}\right)$. 
Tabel 10. Solusi Ideal Positif dan Negatif

\begin{tabular}{|c|ccccc}
\hline & K1 & K2 & K3 & K4 & K5 \\
\hline ideal + & 212,6659043 & 137,1511 & 130,0796 & 69,26325 & 47,15464 \\
ideal - & 212,6423441 & 137,143 & 130,0762 & 69,25976 & 47,13999 \\
\hline
\end{tabular}

Pada tabel 10 menunjukkan hasil dari solusi ideal positif yang diambil dari nilai maksimal normalisasi terbobot dan ideal negatif yang diambil dari nilai minimal normalisasi terbobot.

5. Menentukan jarak antara nilai setiap alternatif dengan matriks solusi ideal positif dan negatif.

Jarak antara alternatif dengan solusi ideal positif ( $\mathrm{Di}+$ ) dan negatif ( $\mathrm{Di}+$ ) sesuai dengan rumus:

Ideal posistif:

$$
D_{i}^{+}=\sqrt{\sum_{j}^{n}=1\left(Y_{i j}-Y_{i}^{+}\right)^{2}}
$$

Ideal negatif:

$$
D_{i}^{-}=\sqrt{\sum_{j}^{n}=1\left(y_{i j}-y_{i}^{-}\right)^{2}}
$$

Jadi hasil jarak nilai alternatif solusi ideal positif dan negatif adalah:

Tabel 11. Hasil Jarak Nilai Alternatif Solusi Ideal Positif dan Negatif.

\begin{tabular}{|c|cc}
\hline Alternatif & $\mathbf{D}^{+}$ & $\mathbf{D}^{-}$ \\
\hline S1 & 0,015140352 & 0,015826 \\
S2 & 0,025407518 & 0,010568 \\
S3 & 0,013058215 & 0,017926 \\
S4 & 0,016797767 & 0,01401 \\
S5 & 0,024465968 & 0,013074 \\
S6 & 0,004425846 & 0,027383 \\
S7 & 0,015092348 & 0,018797 \\
S8 & 0,021036119 & 0,01178 \\
S9 & 0,026117953 & 0,022163 \\
S10 & 0,005634374 & 0,02716 \\
\hline
\end{tabular}

Pada tabel 11 menunjukan hasil nilai dari perhitungan jarak antara alternatif solusi ideal positif (Di+) dan negatif (Di+). Cara perhitungan jarak alternatif solusi ideal positif seperti:

$\mathrm{D} 1=\sqrt{ }(212,6659043-212,6541242) 2+(137,1511-137,1511) 2+(130,0796-130,0796$

)$^{2}+(69,26325-69,25976) 2+(47,15464-47,14579) 2=0,015140352$

$\mathrm{D} 2=\sqrt{ }(212,6659043-212,6423441) 2+(137,1511-137,1511) 2+(130,0796-130,0796$

)$^{2}+(69,26325-69,25976) 2+(47,15464-47,14579) 2=0,025407518$

Cara perhitungan jarak alternatif solusi ideal positif seperti:

$\mathrm{D} 1=\sqrt{ }(212,6541242-212,6423441) 2+(137,1511-137,143) 2+(130,0796-130,0762) 2+(69,2$ $5976-69,25976) 2+(47,14579-47,13999) 2=0,015826$

$\mathrm{D} 2=\sqrt{(212,6423441-212,6423441) 2+(137,1511-137,143) 2+(130,0796-130,0762) 2+(69,2}$ $5976-69,25976) 2+(47,14579-47,13999) 2=0,010568$

Begitupun dengan alternatif lain dengan cara perhitungan yang sama.

6. Menentukan nilai preferensi

Setelah mendapatkan nilai jarak alternatif solusi ideal positif dan negatif kemudian menentukan nilai preferensi terhadap solusi ideal. 
Tabel 12. Hasil Nilai Preferensi

\begin{tabular}{|c|cc}
\hline Alternatif & Preferensi & Ranking \\
\hline S1 & 0,511063757 & 5 \\
S2 & 0,293750429 & 10 \\
S3 & 0,578548878 & 3 \\
S4 & 0,454751671 & 7 \\
S5 & 0,348261362 & 9 \\
S6 & 0,860862596 & 1 \\
S7 & 0,554656393 & 4 \\
S8 & 0,358973381 & 8 \\
S9 & 0,459039515 & 6 \\
S10 & 0,828188666 & 2 \\
\hline
\end{tabular}

Pada tabel 12 merupakan hasil preferensi terhadap solusi ideal. Cara untuk mendapatkan nilai preferensi seperti:

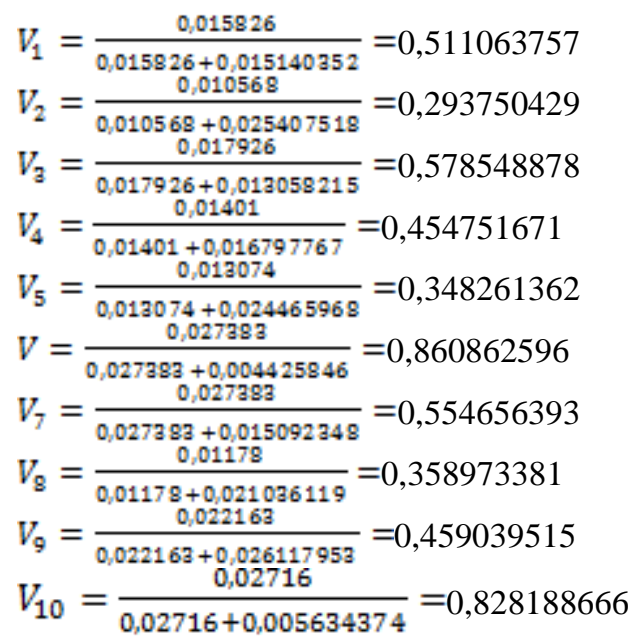

Jadi dari perhitungan di atas didapatkan hasil yang mendapatkan nilai preferensi tertinggi adalah alternatif S6 dengan nilai preferensi 0,860862596.

\section{Kesimpulan}

Berdasarkan hasil dari penelitian dari pengembangan Sistem Penunjang Keputusan Rekomendasi Kelulusan dan Pemeringkatan Santri Menggunakan Metode AHP-TOPSIS pada Pesantren Hajroh Basyir Pati menghasilkan sebuah sistem pendukung keputusan menentukan kelulusan dan pemeringkatan yang diterapkan menggunakan metode AHP-TOPSIS, sehingga dapat menentukan kelulusan dan pemeringkatan santi sesuai dengan kriteria yang telah tentukan. Di dalam sistem yang dirancang dapat digunakan untuk mengelola data admin, data santri, data kriteria, mengelola data nilai, melihat hasil kelulusan dan pemeringkatan menggunakan metode AHP-TOPSIS. Hasil dari sistem pendukung keputusan menghasilkan nilai preferensi tertinggi yaitu 0,860862596 yang dapat membantu menentukan kelulusan dan perankingan santri pondok pesantren Hajroh Basyir Pati. Saran untuk pengembangan sistem selanjutnya, sistem ini dapat dikembangkan menjadi aplikasi berbasis android menyesuaikan kebutuhan pengguna sehingga kinerja sistem dapat meningkat dengan sistem yang lebih user-friendly.

\section{Daftar Pustaka}

[1] A. B. Setiawan and J. Sulaksono, "Sistem Informasi Manajemen Santri di Pondok Pesantren Al Ishlah Kota Kediri,” J. Ilm. NERO, vol. 4, no. 2, pp. 81-86, 2019.

[2] M. N. Hafidzi and N. Santoso, "Sistem Pendukung Keputusan Seleksi Calon Pendidik Menggunakan Metode Analytical Hierarchy Process (AHP) Berbasis Web ( Studi Kasus : PAUD / TK Tanwirul Qulub Kabupaten Pamekasan )," J. Inform. Polinema, vol. 2, no. 3, pp. 116-120, 
2016.

[3] Y. Prihartono and H. Magdalena, "Penerapan Metode Analytical Hierarchy Process (AHP) Sebagai Pendukung Keputusan dalam Menentukan Internet Service Provider Terbaik di Pangkalpinang," J. Sisfokom (Sistem Inf. dan Komputer), vol. 5, no. 1, pp. 21-32, 2016, doi: 10.32736/sisfokom.v5i1.195.

[4] M. P. Ismail, "Sistem Pendukung Keputusan Seleksi Penerimaan Mahasiswa Baru Jalur Beasiswa Dengan Metode TOPSIS (Technique for Order Preference By Similarity To Ideal Solution)," JIKO (Jurnal Inform. dan Komputer), vol. 3, no. 1, pp. 1-10, 2018, doi: 10.26798/jiko.2018.v3i1.79.

[5] D. Puspitasari, M. Mentari, and F. A. Gunawan, "Sistem Pendukung Keputusan Penentuan Penerimaan Mahasiswa Baru Jalur Bidikmisi Menggunakan Metode TOPSIS (Studi Kasus: Politeknik Negeri Malang)," J. Inform. Polinema, vol. 4, no. 1, pp. 63-70, 2017, doi: 10.33795/jip.v4i1.146.

[6] A. Abdullah and M. W. Pangestika, "Perancangan Sistem Pendukung Keputusan Dalam Pemilihan Dosen Pembimbing Skripsi Berdasarkan Minat Mahasiswa dengan Metode AHP (Analytical Hierarchy Process) di Universitas Muhammadiyah Pontianak," JEPIN, vol. 4, no. 3, pp. 184-191, 2018, doi: 10.29406/cbn.v2i02.1297.

[7] A. Mubarok, H. D. Suherman, Y. Ramdhani, and S. Topiq, "Sistem Pendukung Keputusan Kelayakan Pemberian Kredit Dengan Metode TOPSIS,” J. Inform., vol. 6, no. 1, pp. 37-46, 2019, doi: 10.31311/ji.v6i1.4739.

[8] T. I. Ayu, R. Ariyanto, and Y. W. Syaifudin, "Sistem Pendukung Keputusan Kenaikan Jabatan Dengan Metode AHP-TOPSIS (Studi Kasus: Pt. Makmur Citra Abadi),” J. Inform. Polinema, vol. 3, no. 3, pp. 9-14, 2017, doi: 10.33795/jip.v3i3.27.

[9] A. Herdiansah, "Sistem Pendukung Keputusan Referensi Pemilihan Tujuan Jurusan Teknik Di Perguruan Tinggi Bagi Siswa Kelas Xii Ipa Mengunakan Metode AHP," MATRIK J. Manajemen, Tek. Inform. dan Rekayasa Komput., vol. 19, no. 2, pp. 223-234, 2020, doi: 10.30812/matrik.v19i2.579.

[10] R. Umar, A. Fadlil, and Yuminah, "Sistem Pendukung Keputusan dengan Metode AHP untuk Penilaian Kompetensi Soft Skill Karyawan," Khazanah Inform. J. Ilmu Komput. dan Inform., vol. 4, no. 1, pp. 27-34, 2018, doi: 10.23917/khif.v4i1.5978. 